\title{
Review on Teucrium polium biological activities and medical characteristics against different pathologic situations
}

\author{
Mozafar Khazaei, ${ }^{a}$ Seyed Noureddin Nematollahi-Mahani, ${ }^{b}$ Tahmineh Mokhtari, ${ }^{c}$ Fatemeh Sheikhbahaei ${ }^{b}$
}

\author{
aFertility and Infertility Research Center, Kermanshah University of Medical Sciences, Kermanshah, Iran.

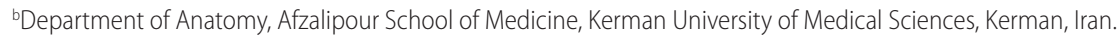 \\ cResearch Center of Nervous System Stem Cells, Department of Anatomy, School of Medicine, Semnan University of Medical Sciences, Semnan, Iran. \\ Correspondence to Fatemeh Sheikhbahaei (email: am23384@gmail.com). \\ (Submitted: 08 September 2017 - Revised version received: 27 September 2017 - Accepted: 13 October 2017 - Published online: 26 March 2018)
}

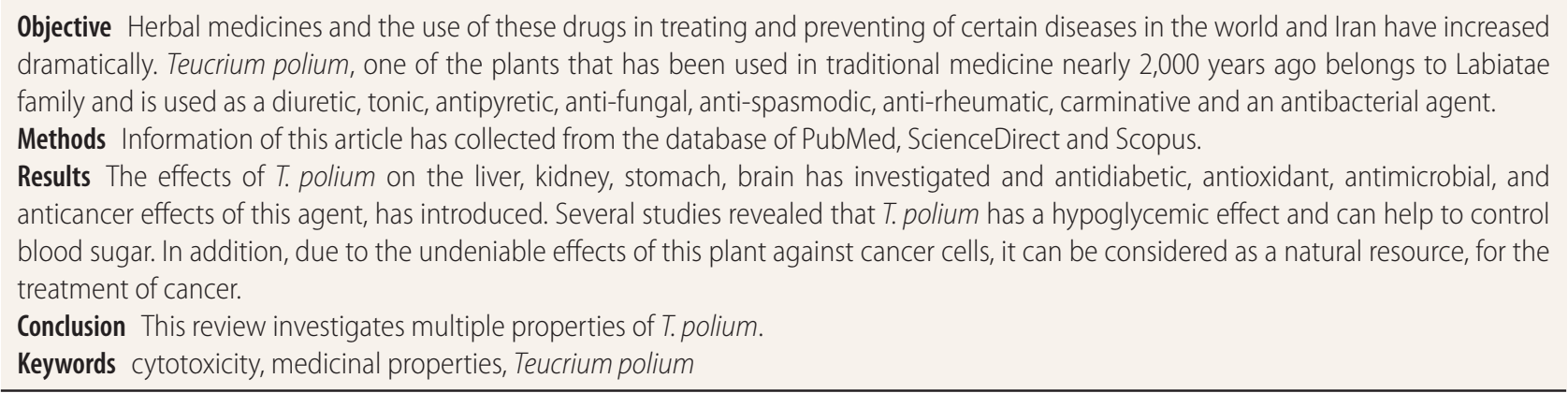

\section{Introduction}

Treatment of various diseases using medicinal plants traced back to ancient times. Teucrium polium, the herb that has used in traditional medicine, almost 2,000 years ago, is found mainly in the Mediterranean region and different areas of Iran especially in semi-arid parts of the mountains and plains. ${ }^{1,2}$ This herbaceous plant, belonging to the Lamiaceae family and flowering time is between June and August. ${ }^{3}$ (Fig. 1). This plant includes 300 species around the world, and has identified in 12 species in Iran. Among them, T. polium, has been used in traditional medicine. ${ }^{4}$ This plant has diuretic, tonic, antipyretic, anti-fungal, anti-spasmodic, anti-rheumatic, carminative and antibacterial properties. ${ }^{5,6}$

Moreover, it has hypoglycemic effects and has been used in diabetic patients as a hypoglycemic agent. Daily consumption of this plant helps to maintain normal levels of blood sugar and can be appropriate for conventional medications to control blood sugar. ${ }^{7}$ In addition, T. polium has antiinflammatory activity, ${ }^{8}$ as well as reduce high body weight and high blood pressure ${ }^{9}$ and has antioxidant and lipidlowering properties.

Numerous studies investigated the effects of T. polium against different pathological situations in different organs. So, in this review, we tried to demonstrate the different biological activates and medical properties of T. polium as a traditional plant. Particularly, we focused on the mechanisms underlying $T$. polium's antioxidant, antibacterial and anticancer properties.

\section{Source and Chemical Compounds of T. polium pheochromocytoma}

Teucrium polium is perennial, herbaceous, with almost woody plants, to a height of $30 \mathrm{~cm}$ and has a white appearance and cotton. Flowers can be seen in white, yellow and white to yellow. This variability is seen not only in color, but also in flower stems that are branched or lying. ${ }^{10} \mathrm{~T}$. polium distributes in rocky and sandy areas of Mediterranean, different parts of Europe, North of Africa and Southwest of Asia, including Iran (in various regions of North, West, South and Central arid mountains). ${ }^{2}$ Some compounds of T. polium have been introduced in different investigations including tannin, terpenoid, saponin, flavonoid, sterol, $\beta$-caryophyllene, diterpenoids, caryophyllene oxide, asparagine, ditryne and resinous substances. ${ }^{11,12}$ Vokou and Bessiere ${ }^{13}$ reported that T. polium contain tannin, terpenoid, saponin, sterol, and flavonoid. It is used in the treatment of gastrointestinal diseases. Several compounds extracted from different parts of this plant have been structurally characterized: including Iridoid, flavonoid, eudesman and clerodane. The first returns to the years 1974-1979. In Egypt, a-pinene, menthofuran, monoterpenes (myrcene, ocimene, pulegone have presented as the main of T. polium components).

$\beta$-Eudesmol has detected in T. polium in Tunisia. ${ }^{14}$ In the region of Saudi Arabia (subspecies not listed), monoterpenes ( $\beta$-pinene, limonene, $\alpha$-phellandrene, linalool, and terpinen- 4 ) and terpenes ( $\gamma$-cadinenes, cedrenol, guaiol) have detected. ${ }^{6}$ In Greece (subspecies not reported), T. polium contains terpenes: $\alpha$ - and $\tau$-cadinols and $\beta$-caryophyllene. ${ }^{13}$ It has been reported that this agent in Spain is rich of monoterpenes that often consisting of $\alpha$ - and $\beta$-pinenes, limonene, terpinen-4 and pinocarveol-18 (Table 1$).{ }^{15}$

\section{Antioxidant Capacity of T. polium}

Therapeutic benefits of medicinal plants are often attributed to their antioxidant properties. ${ }^{16,17}$ Different researches in recent years demonstrated that T. polium has high antioxidant properties. Many species of medicinal plants, especially those belonging to the mint family, such as sage, tucrium, pennyroyal and thyme have strong antioxidant activity. ${ }^{18}$ Number of phenolic compounds with strong antioxidant activity in extracts of these plants have been identified. ${ }^{19}$ HPLC analysis 


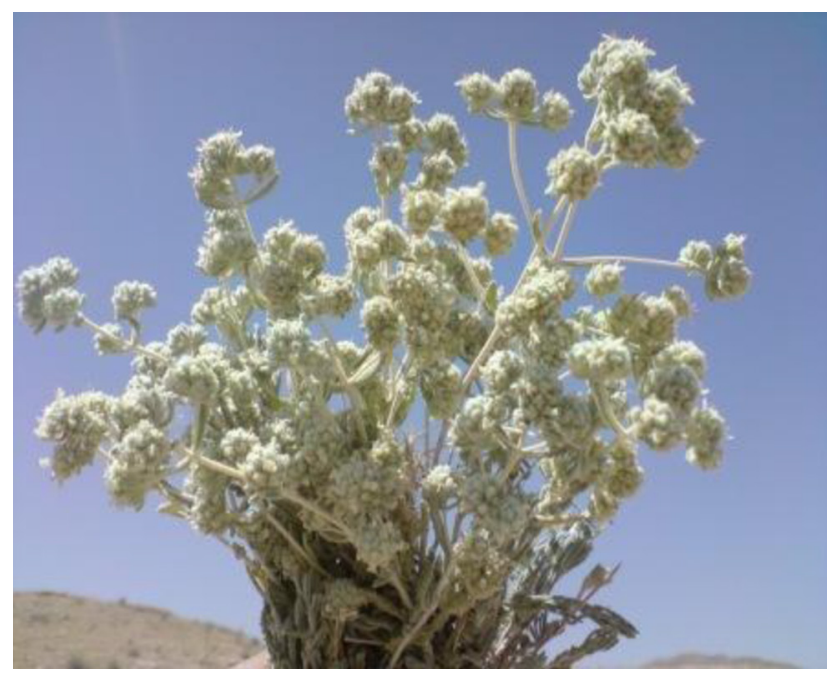

Fig 1. Teucrium polium.

Table 1. Isolated chemical compounds of $\boldsymbol{T}$. polium in different studies

\begin{tabular}{|c|c|c|c|}
\hline Chemical compound & Country & Year & Author (Reference) \\
\hline $\begin{array}{l}\beta \text {-pinene, limonene, } \\
\text { a-phellandrene, lin- } \\
\text { alool, terpinen-4-ol, } \\
\text { y- and } \delta \text {-cadinenes, } \\
\text { cedrol, cedrenol, } \\
\text { guaiol }\end{array}$ & Saudi Arabia & 1979 & Hassan et al. ${ }^{(6)}$ \\
\hline $\begin{array}{l}\text { Tannin, terpenoid, } \\
\text { saponin, sterol, and } \\
\text { flavonoid }\end{array}$ & Greece & 1985 & Vokou et al..(13) \\
\hline $\begin{array}{l}\text { Myrcene, a-pinene, } \\
\text { menthofuran, } \\
\text { ocimene, pulegone }\end{array}$ & Egypt & 1974 & Wassel et al..$^{(14)}$ \\
\hline $\begin{array}{l}\text { a- and } \beta \text {-pinenes, } \\
\text { sabinene, ter- } \\
\text { pinen- } 4-0 l \text { and } \\
\text { pinocarveol }\end{array}$ & Spain & 1993 & Pérez-Alonso(14) \\
\hline
\end{tabular}

showed that the highest levels of flavonoid in T. polium species are in chamaedrys and T. polium. In vitro research showed that T. polium has the antioxidant activity and free radical scavenging activity ${ }^{19,20}$ In several research, the effect of T. polium on oxidation of various tissues have studied and the inhibitory effects of the plant extract against peroxidation, have proved. In this regard, the methanolic extract of T. polium protects red blood cells against lipid peroxidation induced by hydrogen peroxide..$^{21}$ Kadifkova Panovska et al. ${ }^{20}$ reported that different factions of T. polium (diethyl ether, ethyl acetate and $n$-butanol) have inhibitory effect against oxidation. Aqueous extracts prepared from leaves of T. polium, suppresses iron-induced lipid peroxide oxidation in rat liver as well as Trolox, i.e., analog of vitamin $\mathrm{E}$.

\section{Anti-diabetes Effects of T. polium}

Some plants are used as hypoglycemic agents and their extracts have studied in the treatment of diabetic patients. ${ }^{22,23}$ Several animal studies were carried out to evaluate the effect of T. polium on blood glucose concentrations. In a study by Jemal et al. (2012), it was shown that intravenous injection of boiled T. polium caused a significant reduction in blood glucose in diabetic group, compared with a control group that received normal saline. ${ }^{7}$ Hydro-alcoholic extract of T. polium can reduce blood cholesterol and glucose and also improves insulin secretion in diabetic rats. ${ }^{24}$ Esmaeili et al. (2009) reported that flavonoid compounds of $T$. polium, increase insulin secretion from pancreatic beta cells (56\%). This finding was related to flavonoid antioxidant effects of T. polium. ${ }^{25}$ Zal et al. ${ }^{26}$ demonstrated that T. polium decreased blood glucose in diabetic mice and it has been normal within 8 days. Other studies have shown that aqueous extract of T. polium reduces blood sugar in diabetes rat with single dose; it increases insulin secretion and thereby decreases blood glucose in diabetic rats. ${ }^{27}$ But, the extracts of this plant did not have a significant effect on blood sugar of rabbits. ${ }^{28}$ According to studies that evaluated the effect of T. polium on blood sugar levels, it seems that the plant extract may improve insulin function in an animal model. But according to the conflicting reports and deficit of human studies on the effects of this herb on blood sugar level, currently commenting on proven effects of T. polium as hypoglycemic agent is difficult and clinical research seems is necessary.

\section{Anti-cancer Effects of T. polium}

Cancer has remained a major cause of disability and mortality in worldwide..$^{29}$ Despite recent advances in early detection and treatment of cancer, continues to be unstoppable, threatening health and quality of human life. Traditionally, herbal compounds have long been considered in the treatment of cancer and drugs such as doxorubicin and paclitaxel that are derived from plants are also used in the treatment of cancer. Despite the abundance of different plant species in the world, only $1-10 \%$ of plant species composition around the world, have been studied. ${ }^{30}$ In recent years, anti-cancer properties of T. polium have evaluated in several experiments and cytotoxic effects of total extracts and derivatives of this plant against cancer cells has been reported. Anti-cancer properties of this plant know more about to terpenoid and flavonoid compounds. For example, in a study, anti-cancer effect of methanolic extract of T. polium and vincristine, vinblastine and doxorubicin against cell lines is shown: Skmel -3 (melanoma), Saos-2 (osteosarcoma), SW480 (colon cancer), MCF-7 (breast cancer), KB (oral epidermal cell line), EL (bladder carcinoma) and A431 (epidermoid carcinoma). Administration of T. polium and anti-cancer drugs such as vincristine, vinblastine or doxorubicin can enhance the ability of chemotherapy drugs to cancer and also minimizes side effects. ${ }^{31}$ Flavonoids have been considered as the most potent inducer of apoptosis. ${ }^{32}$ Anti-cancer and cytotoxic effects of T. polium in different types of human cell lines is tested such as cervical cancer (HeLa), chronic myeloid (K562), colon cancer (Caco-2, HCT-116, LoVo, SW480), glioblastoma multiforme (REYF-1), hepatoblastoma (HepG2), carcinoma of the larynx (HEP-2), lung cancer (COR-123), prostate cancer (DU145, PC3). ${ }^{33-36}$ Additionally, the cytotoxic effects of ethanolic extract of T. polium in four cell lines were examined to evaluate the formation of colonies: A549 (adenocarcinoma of the lung), BT20 (cancer of the ducts of the breast), MCF7 (breast adenocarcinoma) and PC12 (pheochromocytomaFV mice). As well, they compared cytotoxicity of $T$. polium with taxol, an anti-cancer agent. The results demonstrated that ethanolic extract of T. polium, inhibits growth of all cell lines effectively. 


\begin{tabular}{|c|c|c|}
\hline Authors & Groups & T.polium \\
\hline Twaij (1987) & Rat & Recovery of stomach ulcer \\
\hline Munir (1988) & Rat & A significant reduction in blood glucose concentration \\
\hline Lalibert and Villeneuve (1996) & Human & Lethargy, jaundice, elevated liver enzymes (using T. polium 6 months) \\
\hline Zal et al. (2001) & Rat & Glucose reduction within 8 days \\
\hline Zal et al. (2001) & Rat & Degenerative changes in liver lobules \\
\hline Rasekh (2001) & Hyperlipidemic rat & Lower cholesterol and triglycerides \\
\hline Afifi et al. (2005) & Rabbit & No significant effect on blood sugar \\
\hline $\begin{array}{l}\text { Baluchnejadmojarad T et al. } \\
\text { (2005) }\end{array}$ & Rat & Analgesic effect \\
\hline Shahraki et al. (2006) & Rat & Lower blood sugar levels of diabetic mice \\
\hline Shahraki et al. (2006) & Rat & Analgesic effect of visceral and somatic \\
\hline Panovska et al. (2007) & Rat & Repair and regeneration of liver \\
\hline Mehrabani et al. (2009) & Rat & Reducing gastric ulcer index by $90 \%$ \\
\hline Mousavi (2011) & Rat & Lower obesity parameters \\
\hline Ayoubi et al. (2013) & Rat & Lower glucose in diabetic mice \\
\hline Belmekki et al. (2013) & In vitro & The inhibitory effects on bacteria \\
\hline Tabatabaei et al. (2014) & In vitro & Antimicrobial effect against gram positive bacteria \\
\hline Mousavi et al. (2015) & Rat & Improving the devastating effects of diabetes on memory \\
\hline \multirow[t]{5}{*}{ Nematollahi (2007) } & In vitro & Inhibit the growth of cell lines: \\
\hline & & $\mathrm{IC}_{50}: \mathrm{BT} 20: 106 \mu \mathrm{g} / \mathrm{ml}$ \\
\hline & & $\mathrm{IC}_{50}: \mathrm{MCF}-7: 140 \mu \mathrm{g} / \mathrm{ml}$ \\
\hline & & $\mathrm{IC}_{50}: \mathrm{PC} 12: 120 \mu \mathrm{g} / \mathrm{ml}$ \\
\hline & & $I_{50}: A 549: 90 \mu \mathrm{g} / \mathrm{ml}$ \\
\hline \multirow[t]{2}{*}{ Eskandary (2007) } & In vitro & Reduce the formation of clonal cell lines REYF-1 \\
\hline & & Methanolic extract: $\mathrm{IC}_{50}: 95 \mu \mathrm{g} / \mathrm{ml}$ \\
\hline Mahdinia (2012) & In vitro & Cytotoxicity on (U87) IC $C_{50}: 64.47 \mu \mathrm{g} / \mathrm{ml}$ \\
\hline \multirow[t]{8}{*}{ Rajabalian et al. (2008) } & In vitro & Cytotoxicity on cell lines: \\
\hline & & $\mathrm{IC}_{50}:$ Saos-2:109 $\mu \mathrm{g} / \mathrm{ml}$ \\
\hline & & $\mathrm{IC}_{50}:$ Skmel:3-83 $\mu \mathrm{g} / \mathrm{ml}$ \\
\hline & & $\mathrm{IC}_{50}:$ MCF-7:174 $\mu \mathrm{g} / \mathrm{ml}$ \\
\hline & & $\mathrm{IC}_{50}: \mathrm{SW} 480: 139 \mu \mathrm{g} / \mathrm{ml}$ \\
\hline & & $\mathrm{IC}_{50}: \mathrm{KB}: 174 \mu \mathrm{g} / \mathrm{ml}$ \\
\hline & & $I_{50}: E J: 108 \mu \mathrm{g} / \mathrm{ml}$ \\
\hline & & $\mathrm{IC}_{50}: \mathrm{A} 431: 93 \mu \mathrm{g} / \mathrm{ml}$ \\
\hline \multirow[t]{3}{*}{ Kundaković (2011) } & In vitro & Cytotoxicity on cell lines: \\
\hline & & $\mathrm{IC}_{50}: \mathrm{MDA}-\mathrm{MB}-361: 130 \mu \mathrm{g} / \mathrm{ml}$ \\
\hline & & $\mathrm{IC}_{50}: \mathrm{MDA}-\mathrm{MB}-453: 367 \mu \mathrm{g} / \mathrm{ml}$ \\
\hline \multirow[t]{5}{*}{ Menichin (2009) } & In vitro & Cytotoxicity on cell lines: \\
\hline & & $I_{50}: \operatorname{RAW} 264 / 7: 29 / 4 \mu \mathrm{g} / \mathrm{ml}$ \\
\hline & & $\mathrm{IC}_{50}: \mathrm{CACO}-2: 52 / 7 \mu \mathrm{g} / \mathrm{ml}$ \\
\hline & & $\mathrm{IC}_{50}: 2 \mathrm{C} 32: 91 \mu \mathrm{g} / \mathrm{ml}$ \\
\hline & & $\mathrm{IC}_{50}: 23 \mathrm{COR}-\mathrm{L}: 104 \mu \mathrm{g} / \mathrm{ml}$ \\
\hline
\end{tabular}


Among the cell lines, A549 was more sensitive to PC12. ${ }^{37}$ Cytotoxic and anti-tumor effects of the aqueous and methanolic extract of T. polium on human glioblastoma cell line (REYF-1) has been studied and proved that methanolic extract of T. polium decreases colony formation in a dose-dependent. The methanolic extract was more effective than aqueous extract, due to the better solubility of the active chemical components in methanol. ${ }^{34}$ It has been reported (2012) that terpenoids and antioxidants compounds derived from petroleum ether fraction of T. polium accelerate cytotoxic effects against U87..$^{38}$

\section{Antimicrobial Effects of T. polium}

Teucrium polium aqueous extract has anti-bacterial properties, but anti-fungal effect has not been confirmed. ${ }^{39}$ The results demonstrated that $T$. polium extract significantly has antimicrobial activity in vitro, especially on the strains of gram-positive bacteria. ${ }^{40}$ Oil extracted from the T. polium with a minimum concentration of 3-5 $\mu \mathrm{l} / \mathrm{ml}$, has the inhibitory effect on Bacillus cereus bacteria, Enterococcus faecalis and Escherichia coli. ${ }^{41}$ Raei et al. ${ }^{42}$ confirmed the antibacterial activity of T. polium essential oil against urinary-isolated Klebsiella pneumoniae. Motamedi et al. ${ }^{43}$ evaluated the antibacterial effects of T. polium on Staphylococcus aureus strains and they suggested that T. polium was an effective medicinal plant for treatment of infections caused by $S$. aureus. Sevindik et al. ${ }^{44}$ determined the antimicrobial activity and chemical composition of T. polium essential oils provided from North Anatolian. They showed that this plant had an inhibition effect on resistant micro-organisms including methicillin-resistant Pseudomonas aeruginosa, S. aureus ATCC 6538, S. aureus (MRSA), E. coli Q157:H7 and B. cereus CCM 99. ${ }^{44}$ So, this natural antibacterial source can be carried out to produce new drugs against different bacteria.

\section{Antinociceptive and Analgesic Effects of T. polium}

Oral administration of this plan is used as a visceral analgesic agent. In one study, use of T. polium extract, increased the time of tail reaction to painful stimulus in rats and it can be concluded that this plant extract may has a visceral analgesic in addition to somatic analgesic. Although the exact mechanism, needs further investigation. T. polium extract at a dose of 200 $\mathrm{mg} / \mathrm{kg}$ for a period of 2 weeks, has been created a significant analgesic effect. ${ }^{69}$ Verdi et al. ${ }^{45}$ proved that aqueous extract of T. polium leaves induced antinociceptive effects through the central mechanisms in rat model of pain. Zendehdel et al. ${ }^{46}$ showed that the analgesic effect of T. polium mediated by opioidergic and histaminergic $\mathrm{H} 1$ and $\mathrm{H} 2$ receptors in mice model of visceral pain.

\section{Effects of T. polium on Nervous System Related Disorders}

Teucrium polium extract had positive effects on mice that were suffering from amnesia with scopolamine. It has been reported that $T$. polium extract can significantly reduce lipid peroxidation in the hippocampus and cerebral cortex. Different doses of this agent were able to prevent learning difficulties. ${ }^{47}$ In another study, results revealed T. polium (200 and $400 \mathrm{mg} / \mathrm{kg}$ ), prevents the damaging effects of diabetes on memory, but a dose of $100 \mathrm{mg} / \mathrm{kg}$ T. polium does not has any positive effect on memory disorders. ${ }^{48}$ As well, Mousavi et al. (2015) investigated the beneficial effects of T. polium on diabetes-induced brain tissue oxidative damage and memory deficits in rats. Their findings of proved that $T$. polium protected the rat against the memory impairments induced diabetes by reducing the brain tissues oxidative damage in rats. ${ }^{47}$ Simonyan et al. ${ }^{49}$ demonstrated that hydroponic T. polium had protective effects on hippocampal neurodegeneration by modulating neurotransmitters activates and network plasticity in ovariectomized rats.

\section{Effects of T. polium on Gastric Disorders}

Teucrium polium extract inhibits the movement of the stomach and in traditional medicine; it is used as an antispasmodic. In a study, rats were treated with indomethacin to induce gastric ulcer. T. polium reduced the scarring at a rate of $50 \%$ after a week, $80 \%$ after 2 weeks and $90 \%$ after 4 weeks. The mucosal healing, and the reduction of proliferation, mucosal hyperplasia, migration of inflammatory cells were observed..$^{50}$ This agent at a dose of $150 \mathrm{mg} / \mathrm{kg}$ promoted wound healing at the rate of $50 \%$ in mice that their stomach ulcers were induced by starvation. Whereas, oral consumption of the extract improves gastric ulcers at the rate of $85 \% .^{5}$

\section{Vascular Effects of T. polium}

Teucrium polium decreases aortic smooth muscle contraction induced by $\mathrm{KCl}$ and phenylephrine. Endothelium can inhibit contraction of smooth muscle of vessels through the synthesis and secretion of substances such as nitric oxide (NO) and can induce the contraction through the synthesis and secretion of endothelin. The difference in the effect of the contraction induced by $\mathrm{KCl}$ and phenylephrine in the presence or without endothelium indicates that part of the effect, mediates by endothelium. It seems that factors secreted by the endothelium that effect vessels, are important due to relaxant properties of this plant that effect through the endothelium, In addition to the smooth muscle. This effect mainly applies via the inhibition of calcium influx. ${ }^{5}$

\section{Effects of T. polium on Renal Disorders}

Some herbs may lead to kidney damage and should be used with caution. In a study (2013), the effect of ethanolic extract of T. polium on rat kidney was evaluated. Treatment of mice with doses of $50,100,150,200 \mathrm{mg} / \mathrm{kg}$ for 28 days, did not increase the kidney damage in-group receiving T. polium compared to the control group. However, 28 days after stopping the drug, kidney damage, emerged including degeneration, degradation and vacuolization compared to the control group.

\section{Effects of T. polium on Hepatic Disorders}

In recent years, extensive studies have been done to evaluate the effect of T. polium extract on the liver. In most of these studies, $T$. polium had been caused degenerative changes, necrosis, hepatic toxicity and general side effects. Zal et al. ${ }^{26}$ observed degenerative changes in hepatic lobuls in diabetic rats and it was concluded that although T. polium has hypoglycemic effect, but should be cautious about taking it. In another study, Mehdinia et al. ${ }^{54}$ 
evaluated T. polium fractions of petroleum ether on the mice liver toxicity and their results presented that administration of the extract significantly decreased body weight and changes some liver enzymes. In humans, several cases about liver damage have been reported and in one case after eating T. polium, hepatitis created that need liver transplantation. ${ }^{55}$ In another report, following 5-6 months after taking T. polium, patients getting lethargy, jaundice with elevated liver enzymes and jaundice disappeared after 8 weeks of discontinuation. ${ }^{56}$ In five patients who were given $T$. polium, at least 1 month, liver biopsy showed acute hepatitis in these patients. Liver function tests, 10-30 days after use improved and liver function was normal after 2-6 months. ${ }^{57}$ In another report, 62 years old man, has used tea containing T. polium once daily, due to hypercholesterolemia and diabetes. Then after taking drug for 4 months, getting jaundice and liver biopsy revealed acute hepatitis and necrosis. ${ }^{58}$ Injection of T. polium in doses of $50-150 \mathrm{mg} / \mathrm{kg}$ for 10 days, significantly reduced serum cholesterol and triglyceride levels in rats with hyperlipidemia. ${ }^{12} \mathrm{~A}$ number of studies have also reported that T. polium consumption has cholestatic effects and causes hepatitis symptoms and reduction of the nerve cells conduct. ${ }^{59,60}$ Hepatocyte necrosis, following T. polium, has reported in several studies, as well as elevated liver enzymes such as ALP, ALT, AST. ${ }^{52,61}$ Panovska et al. assessed protective activity of ethyl acetate extract of T. polium against carbon tetrachloride induced liver damage. In this study, injection of T. polium extract induced liver regeneration for 7 days. $^{62}$ Although, T. polium as the herbal medicine, can be useful agent, but according to the studies on the liver, it seems to have toxic effects on this tissue and its use in humans should be done with caution.

\section{Conclusion}

Due to the effect of different species of T. polium on cancer cell lines, this plant can be considered as a natural source of powerful anti-cancer drugs in the future. In addition, due to the important role of angiogenesis in tumor growth, it seems that it is necessary to study anti-angiogenesis effect of $T$. polium, as a confirmation of cancer prevention. Although, T. polium can reduce blood sugar by increasing insulin secretion or increase hepatic metabolism or glucose, but since the aqueous and alcoholic extracts of this plant have hepatotoxic and necrotic properties in liver cells, has limited the therapeutic application of this plant and recommendation to consume in humans requires more studies and surveys.

\section{References}

1. Galati E, Mondello M, D'Aquino A, Miceli N, Sanogo R, Tzakou O, et al. Effects of Teucrium divaricatum Heldr. ssp. divaricatum decoction on experimental ulcer in rats. J Ethnopharmacol. 2000;72:337-342.

2. Naghibi F, Mosaddegh M, Mohammadi Motamed M, Ghorbani A. Labiatae family in folk medicine in Iran: from ethnobotany to pharmacology. Iran J Pharm Res. 2010:4:63-79.

3. Capasso F, de Fusco R, Fasulo M, Lembo M, Mascolo N, Menghini A. Antipyretic and antibacterial actions of Teucrium polium (L.). Pharm Res Commun. 1984:16:21-29.

4. Akin M, Oguz D, Saracoglu H. Antibacterial activity of essential oil from Thymbra spicata var. spicata L. and Teucrium polium (Stapf Brig.) Interventions. 2010;8:53-58.

5. Said O, Khalil K, Fulder S, Azaizeh H. Ethnopharmacological survey of medicinal herbs in Israel, the Golan Heights and the West Bank region. J Ethnopharmacol. 2002:83:251-265.

6. Hassan M, Muhtadi F, Al-Badr A. GLC-mass spectrometry of Teucrium polium oil. J Pharm Sci. 1979;68:800-801.

7. Gharaibeh MN, Elayan HH, Salhab AS. Hypoglycemic effects of Teucrium polium. J Ethnopharmacol. 1988;24:93-99.

8. Tariq M, Ageel A, Al-Yahya M, Mossa J, Al-Said M. Anti-inflammatory activity of Teucrium polium. Int J Tissue React. 1988;11:185-188.

9. Gharaibeh M, Elayan H, Salhab A. Anorexic effect of Teucrium polium in rats. Int J Crude Drug Res. 1989;27:201-207.

10. Ricci D, Fraternale D, Giamperi L, Bucchini A, Epifano F, Burini G, et al. Chemical composition, antimicrobial and antioxidant activity of the essential oil of Teucrium marum (Lamiaceae). J Ethnopharmacol. 2005;98:195-200.

11. Niazmand S, Ahmadpour E, Mousavian M, Saberi Z. The inotropic and chronotropic effects of aqueous ethanolic extract from Teucrium polium I. On guinea pig isolated heart. J Babol Univ Med Sci. 2008:10:7-13.

12. Niazmand S, Hajizade M, Keshavarzi-Poortafti, Z. The effects of aqueous extract from Teucrium polium L. on rat gastric motility in basal and vagalstimulated conditions. Iran J Basic Med Sci. 2007;10:60-65.

13. Vokou D, Bessiere J-M. Volatile constituents of Teucrium polium. J Nat Prod. 1985:48:498-499.

14. Wassel G, Ahmed S. Chemical composition of the wild Egyptian plant Teucrium polium L. Pharmazie. 1974:29:540-541.

15. Ljubuncic P, Azaizeh H, Portnaya I, Cogan U, Said O, Saleh KA, et al. Antioxidant activity and cytotoxicity of eight plants used in traditional Arab medicine in Israel. J Thnopharmacol. 2005;99:43-47.

16. Hertog MG, Feskens EJ, Kromhout D, Hollman P, Katan M. Dietary antioxidant flavonoids and risk of coronary heart disease: the Zutphen Elderly Study. Lancet. 1993:342:1007-1011.
17. Zhang Z, Chang Q, Zhu M, Huang Y, Ho WK, Chen Z-Y. Characterization of antioxidants present in hawthorn fruits. J Nutr Biochem. 2001;12:144-152.

18. Hirasa K, Takemasa M. Spice Science and Technology: CRC Press; New York, USA, 1998

19. Shahidi F. Natural Antioxidants: Chemistry, Health Effects, and Applications: The American Oil Chemists Society; Illinois, USA, 1997.

20. Kadifkova Panovska T, Kulevanova S, Stefova M. In vitro antioxidant activity of some Teucrium species (Lamiaceae). Acta Pharm. 2005;55:207-214

21. Suboh S, Bilto Y, Aburjai T. Protective effects of selected medicinal plants against protein degradation, lipid peroxidation and deformability loss of oxidatively stressed human erythrocytes. Phytother Res. 2004;18:280-284.

22. Torres IC, Suarez JC. A preliminary study of hypoglycemic activity of Lythrum salicaria. J Nat Prod. 1980:43:559-563.

23. Jimenez J, Risco S, Ruiz T, Zarzuelo A. Hypoglycemic activity of Salvia lavandulifolia. Planta Med. 1986:52:260-262.

24. Ayoubi A, Omidi A, Valizade R, Mousaei A. Effect of hydroalcoholic extract of Aloevera and Teucrium on serum glucose and lipid profile in streptozotocin diabetic male rats. J Birj Univ Med Sci. 2013:20:144-152.

25. Esmaeili MA, Zohari F, Sadeghi H. Antioxidant and protective effects of major flavonoids from Teucrium polium on $\beta$-cell destruction in a model of streptozotocin-induced diabetes. Planta Med. 2009;75:1418-1420.

26. Zal F, Vasei M, Rasti M, Vessal M. Hepatotoxicity associated with hypoglycemic effects of Teucrium polium in diabetic rats. Arch Iran Med. 2001:4:188-192.

27. Shahraki M, Miri ME, Palan M, Mirshekari H, Shahraki E. The survey of Teucrium polium toxicity effect on liver and serum lipoproteins in normoglycemic male rats. Zahedan J Res Med Sci. 2006;8:227-232.

28. Afifi F, Al-Khalidi B, Khalil E. Studies on the in vivo hypoglycemic activities of two medicinal plants used in the treatment of diabetes in Jordanian traditional medicine following intranasal administration. J Ethnopharmacol. 2005:100:314-318.

29. Jemal A. Global burden of cancer: opportunities for prevention. Lancet. 2012;380:1797-1799.

30. Verpoorte R. Pharmacognosy in the new millennium: leadfinding and biotechnology. J Pharm Pharmacol. 2000;52:253-262.

31. Rajabalian S. Methanolic extract of Teucrium polium L. potentiates the cytotoxic and apoptotic effects of anticancer drugs of vincristine, vinblastine and doxorubicin against a panel of cancerous cell lines. Exp Oncol. 2008:30:133-138

32. Haïdara K, Alachkar A, Al Moustafa A-E. Teucrium polium plant extract provokes significant cell death in human lung cancer cells. Health. 2011;3:366 
33. Abu-Dahab R, Afifi F. Antiproliferative activity of selected medicinal plants of Jordan against a breast adenocarcinoma cell line (MCF7). Sci Pharm. 2007;75:121-146.

34. Line MC. Evaluation of cytotoxic effect of Teuerium polium on a new glioblastoma multiforme cell line (REYF-1) using MTT and soft agar clonogenic assays. Int J Pharmacol. 2007;3:435-437.

35. Kandouz M, Alachkar A, Zhang L, Dekhil H, Chehna F, Yasmeen A, et al. Teucrium polium plant extract inhibits cell invasion and motility of human prostate cancer cells via the restoration of the E-cadherin/catenin complex. J Ethnopharmacol. 2010;129:410-415.

36. Stankovic MS, Curcic MG, Zizic JB, Topuzovic MD, Solujic SR, Markovic SD. Teucrium plant species as natural sources of novel anticancer compounds: antiproliferative, proapoptotic and antioxidant properties. Int J Mol Sci. 2011;12:4190-4205.

37. Nematollahi-Mahani S, Rezazadeh-Kermani M, Mehrabani M, Nakhaee N. Cytotoxic effects of Teucrium polium on some established cell lines. Pharm Biol. 2007:45:295-298.

38. Mahdinia Z, Eftekharvaghefi R, Nabipour F. In vitro inhibition of the growth of glioblastoma by Teucrium polium crude extract and fractions. Int J Phytomed. 2013;4:582-588.

39. Mosadegh M, Dehmoubed Sharifabadi A, Nasiri P, Esmaeili S, Naghibi F. The study of phytochemical, antifungal and antibacterial effects of Teucrium polium and Cichourium intybus. Sci J Kurdistan Univ Med Sci. 2002;7:1-6.

40. Tabatabaei YF, Alizadeh BB, Heidari SM, Mortazavi S. The in vitro study of antimicrobial effect of Teucrium polium extract on infectious microorganisms. Sci J Hamadan Univ Med Sci. 2014;21:16-24.

41. Belmekki N, Bendimerad N, Bekhechi C. Chemical analysis and antimicrobial activity of Teucrium polium L. essential oil from Western Algeria. J Med Plant Res. 2013;7:897-902

42. Raei F, Ashoori N, Eftekhar F, Yousefzadi M. Chemical composition and antibacterial activity of Teucrium polium essential oil against urinary isolates of Klebsiella pneumoniae. J Essent Oil Res. 2014;26:65-69.

43. Motamedi H, Alivand S, Ebrahimian M, Moosavian S. The antibacterial properties of methanolic extract of Teucrium polium against MRSA J Kermanshah Univ Med Sci. 2015;18:557-562.

44. Sevindik E, Abacı ZT, Yamaner C, Ayvaz M. Determination of the chemical composition and antimicrobial activity of the essential oils of Teucrium polium and Achillea millefolium grown under North Anatolian ecological conditions. Biotechnol Biotechnol Equip. 2016:30:375-380.

45. Verdi J, Komeilizadeh H, Kamalinejad M, Sh S. Analgesic effects of aqueous extract of Teucriun polium $\mathrm{L}$. in experimental models of pain in male rats. Iran J Pharm Res. 2010:62.

46. Zendehdel M, Taati M, Jadidoleslami M, Bashiri A. Evaluation of pharmacological mechanisms of antinociceptive effect of Teucrium polium on visceral pain in mice. Iran J Vet Res. 2011;12:292-297.
47. Mousavi SM, Niazmand S, Hosseini M, Hassanzadeh Z, Sadeghnia HR, Vafaee $F$, et al. Beneficial effects of Teucrium polium and metformin on diabetes-induced memory impairments and brain tissue oxidative damage in rats. Int J Alzheimer's Dis. 2015:2015:493729.

48. Hasanein P, Shahidi S. Preventive effect of Teucrium polium on learning and memory deficits in diabetic rats. Med Sci Monit. 2012;18:BR41.

49. Simonyan K, Chavushyan V. Protective effects of hydroponic Teucrium polium on hippocampal neurodegeneration in ovariectomized rats. BMC Complement Altern Med. 2016;16:415.

50. Mehrabani D, Rezaee A, Azarpira N, Fattahi MR, Amini M, Tanideh N, et al. The healing effects of Teucrium polium in the repair of indomethacin-induced gastric ulcer in rats. Saudi Med J. 2009;30:494-499.

51. Twaij HA, Albadr AA, Abul-Khail A. Anti-ulcer activity of Teucrium polium. Int J Crude Drug Res. 1987;25:125-128.

52. Feridoni E, Niazmand S, Harandizadeh F, Hosseini S, Mahmodabadi M. Vasorelaxant effect of hydroalcoholic extract of Teucrium polium I. On isolated rat aorta. 2012;1:35-44.

53. Rafieian-Kopaei M, Baradaran A. Teucrium polium and kidney. J Renal Inj Prev. 2013;2:3.

54. Mehdinia Z, Eftekhar-Vaghefi R, Mehrabani M, Nabipour F, Mehdinia $\mathrm{N}$, Nematollahi-Mahani SN. The effect of petroleum ether fraction of Teucrium polium extract on laboratory mouse liver. J Kerman Univ Med Sci. 2013;20:279-291.

55. Mattéi A, Pierre R, Didier S, Cyril F, Michel R, Henri B. Liver transplantation for severe acute liver failure after herbal medicine. J Hepatol. 1995;22:597.

56. Laliberte L, Villeneuve J-P. Hepatitis after the use of germander, a herbal remedy. CMAJ. 1996;154:1689.

57. Savvidou S, Goulis J, Giavazis I, Patsiaoura K, Hytiroglou P, Arvanitakis C. Herb-induced hepatitis by Teucrium polium L.: Report of two cases and review of the literature. Eur J Gastroenterol Hepatol. 2007;19:507-511.

58. Mazokopakis E, Lazaridou S, Tzardi M, Mixaki J, Diamantis I, Ganotakis E. Acute cholestatic hepatitis caused by Teucrium polium L. Phytomedicine. 2004;11:83-84

59. Polymeros D, Kamberoglou D, Tzias V. Acute cholestatic hepatitis caused by Teucrium polium (golden germander) with transient appearance of antimitochondrial antibody. J Clin Gastroenterol. 2002:34:100-101.

60. Shahraki MR, Arab MR, Mirimokaddam E, Palan MJ. The effect of Teucrium polium (Calpoureh) on liver function, serum lipids and glucose in diabetic male rats. Iran Biomed J. 2007;11:65-68.

61. Forouzandeh H, Azemi ME, Rashidi I, Goudarzi M, Kalantari H. Study of the protective effect of Teucrium polium L. extract on acetaminophen-induced hepatotoxicity in mice. Iran J Pharm Res. 2013;12:123-129.

62. Panovska T, Kulevanova S, Gjorgoski I, Bogdanova M, Petrushevska G. Hepatoprotective effect of the ethyl acetate extract of Teucrium polium L. against carbontetrachloride-induced hepatic injury in rats. Acta Pharm. 2007;57: 241-248. 